\title{
Evaluation of kaolin and bauxite from the Amazonian region addition on mechanical-, physical-, chemical properties and microstructural characterization of red ceramic industry clay of Manaus metropolitan region
}

Ana Letícia Colombo ${ }^{1}$, Felipe Barros Laraz ${ }^{1}$, José Ferreira da Silva Júnior ${ }^{2}$ Raimundo Humberto Cavalcante Lima $^{3}$, Lucas Freitas Berti ${ }^{4}$

\footnotetext{
${ }^{1}$ Universidade Tecnológica Federal do Paraná, Department of Materials Science and Engineering - Londrina, Paraná, BR +55 41 3279-6671

e-mail: ana_le_ti@yahoo.com.br / felipebarros.laraz@gmail.com

${ }^{2}$ Universidade Federal da Integração Latino-Americana, Latin American Institute of Technology, Infrastructure and Territory - Foz do Iguaçu, PR, BR

e-mail: ferreirajr@gmail.com

${ }^{3}$ Universidade Federal do Amazonas, Department of Geosciences - Manaus, AM, BR - +55 92 3305-2869

e-mail: humbertoclima@yahoo.com.br

${ }^{4}$ Universidade Tecnológica Federal do Paraná, Department of Mechanical Engineering - Rua Deputado Heitor Alencar

Furtado, 5000 - Ecoville - Sede Ecoville -Curitiba, Paraná, BR 81280-340 - +55 41 3279-6671

e-mail: lenberti@gmail.com
}

\begin{abstract}
The present work investigated properties of red ceramic from the Amazonian region after the addition of kaolin and bauxite mixture with $0,10,20$ and 30\%wt. in red ceramic industry clay. Assessed mechanical properties were flexural strength and Young's modulus. The assessed physical properties were density and porosity. The microstructural images were assessed with SEM and OM microscopies. The fired samples XRD, the raw materials XRF and the XRD were made for chemical composition and present phases assessments. Samples were manufactured by uniaxial compaction and fired at $1200^{\circ} \mathrm{C}$ and $1250^{\circ} \mathrm{C}$. Samples without the mixture of kaolin/bauxite presented higher assessed properties, with approximately $32 \mathrm{MPa}$ of flexural strength and $12 \%$ of porosity with $2.3 \mathrm{~g} / \mathrm{cm}^{3}$ density. Although the initial idea of this work was to add the mixture of kaolin/bauxite in the red ceramic industry clay for improving assessed properties of red ceramic fired parts, the red ceramic industry clay without addition presented better properties. Such properties were attributed to the high aluminous materials content in the raw material. This behaviour is correlated to the fact that bauxite from this region presents $55 \%$ wt. of iron oxide content with aluminium oxide content lower than $25 \%$ wt. Additionally, the assessed properties of the ceramic industry parts fired at $1250{ }^{\circ} \mathrm{C}$ presented this material as promising material for ceramic products with a better added value.
\end{abstract}

Keywords: Red Ceramic Industry, Red Ceramic Raw Materials, Characterization.

\section{INTRODUCTION}

Previous works concerning the development of synthetic agglomerates for use in civil construction industry showed that the metropolitan region of Manaus has some particular characteristics, such as distance from big centres and sedimentary basin, which enables the feasibility of use and development of synthetic aggregates. The sedimentary basin and the distance from big centres cause the use of rock based aggregate to cost high for this region [1,2]. Studies focusing the development of mass formulation for red ceramic industry clay show the relevance of this field of research [3]. In the literature, the development of mullite from decomposition of kaolinite is addressed to be feasible at temperatures around $1200^{\circ} \mathrm{C}$ and additionally, this decomposition reaction results in mullite and quartz [4,5]. Aluminous content of bauxite (considering a conventional bauxite, which is $70 \%$ wt.) can be used in order to suitably react with the residual quartz left from kaolinite decomposition and react to form more mullite. In this context, the initial idea of this work was to use such raw materials obtained from the metropolitan region of Manaus for manufacturing high mullite content ceramics. Therefore, a stoichiometric mixture for formation of mullite from kaolin and bauxite from the Manaus 
region was added to red ceramic industry clay in 0,10, 20 and 30\%wt. and this mass was fired at two different temperatures, i.e. $1200^{\circ} \mathrm{C}$ and $1250^{\circ} \mathrm{C}$, for assessment of mechanical-, physical-, chemical properties and microstructural characterization.

\section{MATERIALS AND METHODS}

This work focused on investigating some properties of the Amazonian red ceramic clay with added raw materials to develop ceramic phases (e.g. mullite). Therefore, the Amazonian raw materials from the vicinity of Manaus city were used. Kaolin was collected from the location with Lat $02^{\circ} 52^{\prime} 49.7^{\prime \prime} \mathrm{S}$ - Long 59²1'38.1” $\mathrm{W}$, near to Itacoatiara city (P1 in map of Figure 1) and red ceramic industry clay from the location eith Lat $03^{\circ} 08^{\prime} 22.3^{\prime}$ S - Long $60^{\circ} 21^{\prime} 40.3^{\prime}$ W W, near to Iranduba city (P2 in map of Figure 1) and bauxite from the location with Lat $02^{\circ} 03^{\prime} 0.6^{\prime \prime} \mathrm{S} 59^{\circ} 55^{\prime} 05.4^{\prime}$ ' W, near to Presidente Figueiredo city (P3 in map of Figure 1). These raw materials were characterized by means of present phases (X-Rays diffractometry - XRD) and chemical composition (X-Rays Fluorescence - XRF).

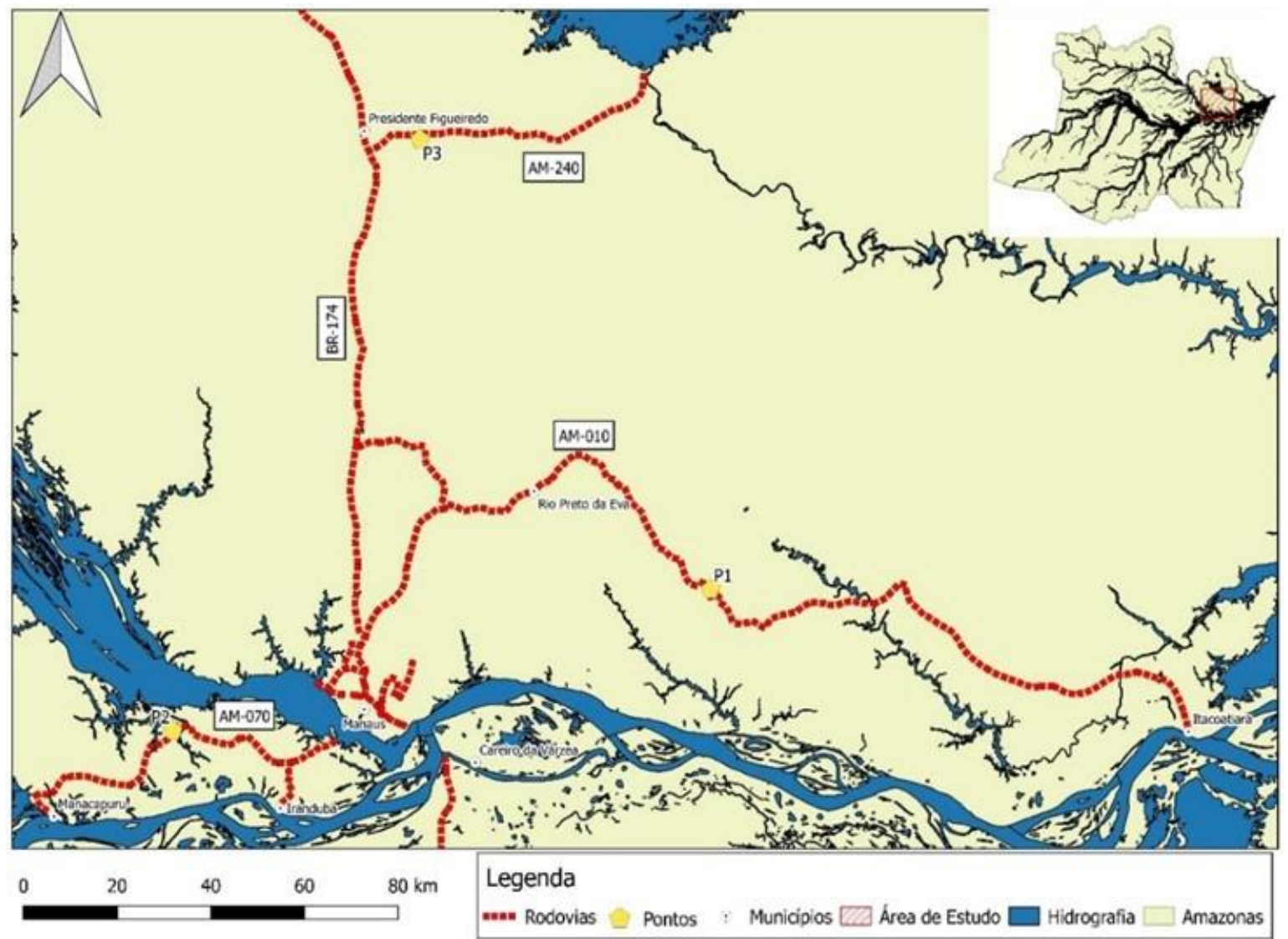

Figure 1: Area from where samples were collected

The reaction of mullite formation from kaolin decomposition, according to Chen and co-workers [4, 5], is given in equations from (1) to (4); and the Stoichiometric formation of mullite from kaolin decomposition is showed in equation (5). These equations are presented in Table1. 
Table 1: Mullite formation from kaolin decomposition reactions equations.

\begin{tabular}{|c|c|}
\hline For temperatures between 500 and $600^{\circ} \mathrm{C}$ : & \\
\hline $\mathrm{Al}_{2} \mathrm{O}_{3} \cdot 2 \mathrm{SiO}_{2} \cdot 2 \mathrm{H}_{2} \mathrm{O}_{\text {(kaolinite) }} \rightarrow \mathrm{Al}_{2} \mathrm{O}_{3} \cdot 2 \mathrm{SiO}_{2 \text { (metakaolinite) }}+2 \mathrm{H}_{2} \mathrm{O}$ & $(1)$ \\
\hline For temperatures between 925 and $1050^{\circ} \mathrm{C}$ : & \\
\hline $2\left(\mathrm{Al}_{2} \mathrm{O}_{3} \cdot 2 \mathrm{SiO}_{2}\right) \rightarrow 2 \mathrm{Al}_{2} \mathrm{O}_{3} \cdot 3 \mathrm{SiO}_{2 \text { (Spinel) }}+\mathrm{SiO}_{2 \text { (amorphous silicon oxide) }}$ & $(2)$ \\
\hline For temperatures, higher than $1100^{\circ} \mathrm{C}$ : & \\
\hline $3\left(2 \mathrm{Al}_{2} \mathrm{O}_{3} \cdot 3 \mathrm{SiO}_{2}\right) \rightarrow 2\left(3 \mathrm{Al}_{2} \mathrm{O}_{3} \cdot 2 \mathrm{SiO}_{2}\right)_{(\text {mullite } 3: 2)}+5 \mathrm{SiO}_{2 \text { (amorphous silicon oxide) }}$ & (3) \\
\hline For temperatures, higher than $1200^{\circ} \mathrm{C}$ : & \\
\hline $\mathrm{SiO}_{2 \text { (tridimite) }} \rightarrow \mathrm{SiO}_{2 \text { (cristobalite) }}$ & $(4)$ \\
\hline For temperatures, higher than $1200^{\circ} \mathrm{C}$ : & \\
\hline $3\left(2 \mathrm{SiO}_{2} \cdot \mathrm{Al}_{2} \mathrm{O}_{3} \cdot 2 \mathrm{H}_{2} \mathrm{O}\right)+6\left(\mathrm{Al}_{2} \mathrm{O}_{3}\right)_{\text {(aluminous carrier) }} \rightarrow 3\left(3 \mathrm{Al}_{2} \mathrm{O}_{3} \cdot 2 \mathrm{SiO}_{2}\right)+6 \mathrm{H}_{2} \mathrm{O}$ & $(5)$ \\
\hline
\end{tabular}

Stoichiometric mullite formation from kaolin decomposition equation was used to produce a ceramic mixture of kaolin plus bauxite minerals (bauxite was meant to be the aluminous content carrier). This stoichiometric ceramic mixture was added to the red ceramic industry clay in amounts of $0,10,20$ and $30 \%$ wt. to form the samples with the ceramic mixture from where the characterizations underwent. For producing these mixtures all raw materials were milled with mortar and pestle and then sieved in 200\# mesh. Afterwards these mixtures (Stoichiometric ceramic mixture plus red ceramic industry clay) were humidified with deionized water by adding $7 \% \pm 1 \%$ wt. The humidified mixture rested for $24 \mathrm{~h}$ in closed plastic bag for homogenizing. The compaction of samples used a die with dimension of $8 \times 60 \mathrm{~mm}$ and samples had weight of $10 \pm 1 \mathrm{~g}$. The used algorithm for compaction was $40 \mathrm{MPa}$ for 5 seconds and relief pressure for deaerating and final compaction of $80 \mathrm{MPa}$ held for 20 seconds. After compaction, the samples dried for 3 hours at $100^{\circ} \mathrm{C}$ in a laboratory stove. Afterwards, a muffle furnace was used for heat treating samples from room temperature to two different isothermals, i.e. $1200^{\circ} \mathrm{C}$ and $1250^{\circ} \mathrm{C}$, using a $5^{\circ} \mathrm{C} \mathrm{min}^{-1}$ ramp from room temperature to $800^{\circ} \mathrm{C}$ and a $3{ }^{\circ} \mathrm{C} \mathrm{min}^{-1}$ ramp from $800^{\circ} \mathrm{C}$ to the final isothermal with soaking time of 120 minutes. Eight groups of three samples each were separated, i.e. 4 groups of $0 \%, 10 \%, 20 \%$ and $30 \%$ wt. addition treated at $1200^{\circ} \mathrm{C}$ and other 4 groups treated at $1250^{\circ} \mathrm{C}$. These groups were characterized by means of mechanical strength, Young's modulus, density, porosity, present phases (XRD analysis) and chemical composition (XRF analysis).

For flexural strength (universal test machine - SHIMADZU, model WDW-100E), three-point bending test using spam of $30 \mathrm{~mm}$ with load cell of $500 \mathrm{~N}$ and deformation speed of $5 \mathrm{~mm} / \mathrm{min}$ was employed for flexural strength values determination. Three samples in each group were selected to determine flexural strength.

For Young's modulus, the non-destructive test dynamic Young's Modulus by Impulse Excitation of Vibration was used. The test consists of a mechanical impulse, provided manually with a small punch (driver), on top of the samples, which is located over support wires at $22.4 \%$ of sample length $\left(0.224 \mathrm{~L}-1^{\text {st }}\right.$ harmonic node for flexural mode). At another extremity, a microphone (detector) is placed and it identifies material's resonant frequencies that are proportional to Young's modulus of the material. The device program, which was previously calibrated, treats these frequencies and then it returns the determined values for the Young's modulus of materials. For more information about this test, refer to standard ASTM E1875-13 [6]. Two samples of each group were used and determinations were made in triplicate for each sample.

Porosity and density were determined by Archimedes' principle, 3 samples of each group had its dry-, wet- and apparent weights $\left(\mathrm{W}_{\mathrm{d}}, \mathrm{W}_{\mathrm{w}}\right.$ and $\mathrm{W}_{\mathrm{a}}$, respectively) measured with precision scale of $0.0005 \mathrm{~g}$ resolution and a porosity determination kit placed over it. Density were determined according to the equations (6) and (7), respectively, $\rho_{\mathrm{w}}$ is water density at room temperature $\left(0.9978 \mathrm{~g} / \mathrm{cm}^{3}\right.$ was the used value $)$. 


$$
\begin{aligned}
& \left(\frac{W_{\mathrm{d}}}{W_{\mathrm{w}}-W_{\mathrm{a}}}\right) \times \rho_{\mathrm{w}} \\
& \left(\frac{\mathrm{W}_{\mathrm{w}}-\mathrm{W}_{\mathrm{d}}}{\mathrm{W}_{\mathrm{w}}-\mathrm{W}_{\mathrm{a}}}\right) \times 100 \%
\end{aligned}
$$

For raw materials XRF analysis (Epsilon $3^{\mathrm{x}}$ - PANalytical - Laboratório de Materiais da Amazônia e Compósitos (LAMAC) - UFAM), samples milled with mortar and pestle were analysed with Standardless calibration STD-1 method for determination of chemical elements from Sodium to Americium. Loss on ignition was done at $1020^{\circ} \mathrm{C}$ for $2 \mathrm{~h}$.

For raw materials XRD analysis (SHIMADZU XRD6000 - Philips - Laboratório de Materiais da Amazônia e Compósitos (LAMAC) - UFAM), samples milled with mortar and pestle were analysed with $\mathrm{Cu}$ $\mathrm{K} \alpha$ radiation with angular range $5 \leq 2 \theta \leq 60^{\circ}$ and $0.02^{\circ}$ step and a fixed exposition time of 5 seconds per step.

For fired samples XRD analysis (X'Pert PRO MPD - PANallytical - Laboratório de Difração de Raios X (LARX) UEL), samples milled with mortar and pestle were analysed with $\mathrm{Cu}-\mathrm{K} \alpha$ radiation with angular range $10 \leq 2 \theta \leq 70^{\circ}$ and $0.02^{\circ}$ step and a fixed exposition time of 2 seconds per step.

For Scanning Electron Microscopy (SEM) (EVO MA 15 - Carl Zeiss - Centro Multiusuário de Caracterização de Materiais - CMCM daUTFPR), one sample of each group selected from fractured samples of three-point bending test were used for collecting SEM micrographs. BSE detector was used for showing composition characteristics using $20 \mathrm{kV}$ of electron acceleration tension after Au surface coating and magnifications of 200x was used to have a wider view.

For Optical Microscopy (OM) (Axio Scope - Carl Zeiss - UTFPR) one sample of each group fired at $1250^{\circ} \mathrm{C}$ selected from fractured samples of three-point bending test were used for collecting OM micrographs. Samples were prepared with sand paper number from 220 to 1200 and polished with alumina paste $0.3 \mu \mathrm{m}$ in a polish machine (Fortel - model PFL). Imagens were collected with a CCD camera (Axio Cam ERc 5s) place on the Axio Scope microscope.

\section{RESULTS AND DISCUSSION}

As mentioned previously, the metropolitan region of Manaus presents a condition where, for rock based aggregate to be used the extraction has to be done in mineral deposits beneath 15 meter in the soil. This fact increases the operation costs and consequently the overall costs. Additionally, it encourages researchers to develop works in synthetic aggregates that might be used in civil construction industry. In this context, the used of affordable raw materials, which appear in open sky, were used in this work.

The chemical compositions of the used raw materials, i.e. kaolin, bauxite and red ceramic industry clay, are presented in Table 2.

Table 2: Raw materials' composition of

\begin{tabular}{l|l|l|l}
\hline Elemental Oxides & Kaolin & Bauxite & Red ceramic clay \\
\hline $\mathrm{SiO}_{2}$ & 56.54 & 14.11 & 47.89 \\
\hline $\mathrm{Al}_{2} \mathrm{O}_{3}$ & 40.68 & 25.21 & 33.07 \\
\hline $\mathrm{TiO}_{2}$ & 0.98 & 0.74 & 1.63 \\
\hline $\mathrm{Fe}_{2} \mathrm{O}_{3}$ & 0.823 & 58.92 & 3.4 \\
\hline $\mathrm{P}_{2} \mathrm{O}_{5}$ & 0.40 & 0.40 & 0.1 \\
\hline $\mathrm{K}_{2} \mathrm{O}$ & 0.33 & $<0.1$ & 0.64 \\
\hline L. O. I & $<0,1$ & $<0,1$ & 13,15 \\
\hline Else & Under 0.2 & Under 0.2 & Under 0.15 \\
\hline
\end{tabular}


Kaolin raw material presented $40.68 \%$ wt. of aluminous content $\left(\mathrm{Al}_{2} \mathrm{O}_{3}\right)$, which is practically the composition of pure kaolinite (45.90\% of aluminous content), and considering this amount is composed totally of kaolinite, the raw material presents $\sim 90 \%$ of kaolinite phase and $\sim 10 \%$ of free quartz, which corresponds to $5.84 \%$ wt. of $\mathrm{SiO}_{2}$ content. This observation is plausible considering the patterns of XRD where characteristics quartz patterns presented lower number of arbitrary unit counts, refer the kaolin patterns in Figure 2.
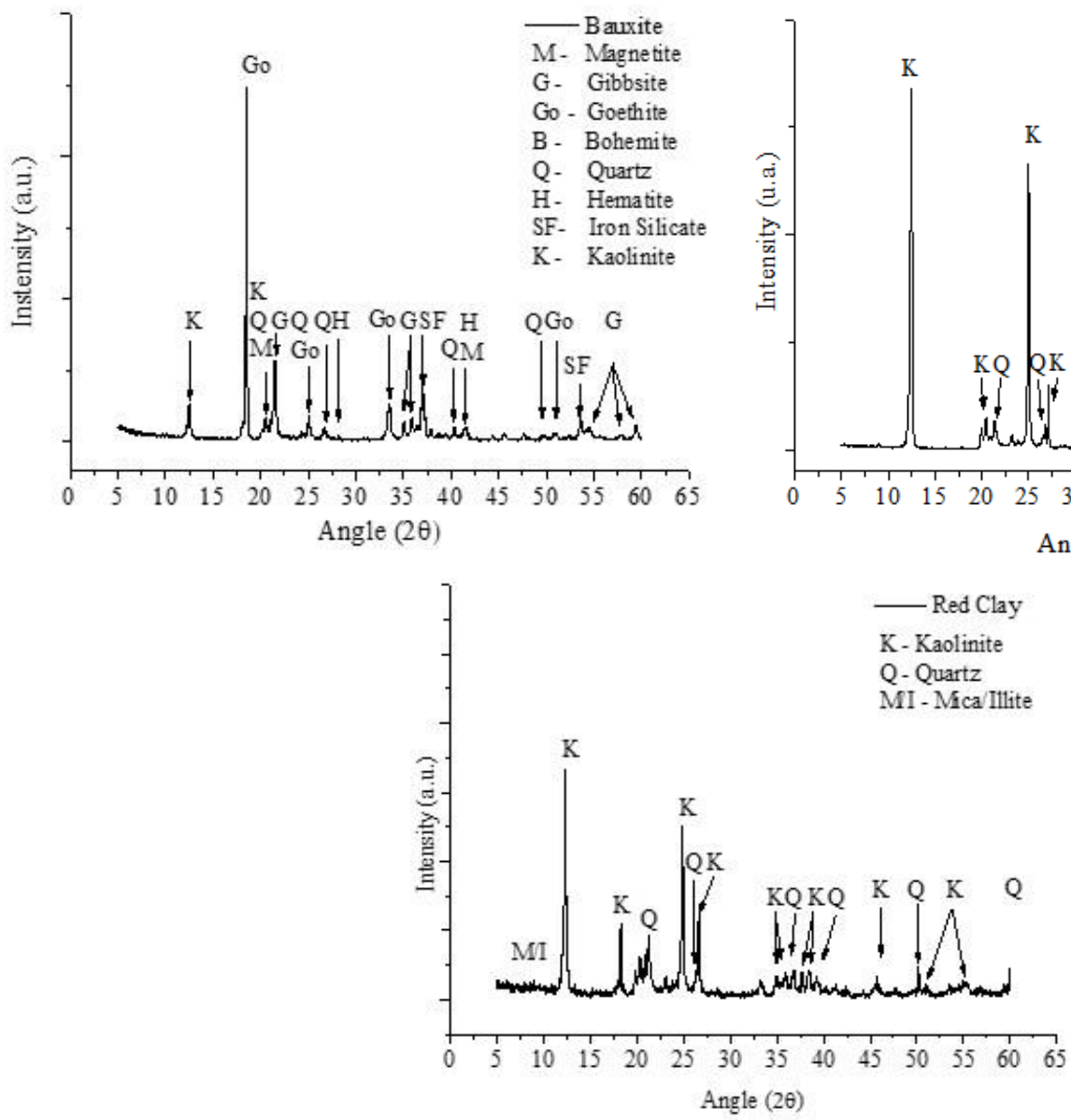

Figure 2: XRD of bauxite, kaolin and red ceramic industry clay samples

This kaolin presented a coloration closer to white before firing process. Bauxite raw material presented only $25.21 \%$ of aluminous content, placing this raw material within a classification as marginal bauxite, i.e. low aluminous content raw material. Moreover, the ferrous content was $58.92 \%$, which is probably caused by the proximity of the lateritic mineral deposit where the bauxite mineral was placed/collected. From the bauxite patterns in Figure 2, several phases are present (i.e. magnetite, gibbsite, goethite, boehmite, quartz, hematite, iron silicate and even kaolinite), and it corroborate the affirmation where this bauxite was placed within a marginal bauxite classification. Furthermore, the iron phases present in bauxite, i.e. goethite, magnetite and hematite, are consistent with the XRF amount of iron content presented in Table 2. This bauxite presented coloration a dark red before the firing process. Red ceramic industry clay presented $33.07 \%$ wt. of aluminous content and $47.89 \%$ wt. of siliceous content. If loss on ignition (13.15\%wt.) is taken off of the account, the corrected values for aluminous content would be $38.07 \%$ wt. and for siliceous content would be $55.14 \%$ wt and rutile content is $1.87 \%$ wt. This observation demonstrates that this red ceramic industry clay has a composition closer to a kaolin mineral with mica/illite content, refer the red ceramic industry clay patterns in Figure 2. In some extend, mica/illite is not a deleterious content for ceramics mass. This red ceramic is classified as quaternary lowland clay due to the place where its mineral deposit is placed (for more information, refer to Figure 1). This clay presented coloration closer to cream before firing process, which is addressed to the $3.40 \%$ wt. of ferrous content. 
The flexural strengths and Young's moduli trends of the samples were similar in comparison to each other, where samples with $0 \%$ of ceramic mixture addition presented values at $1200^{\circ} \mathrm{C}$ lower than values at $1250^{\circ} \mathrm{C}$, referring to Figure 3 .
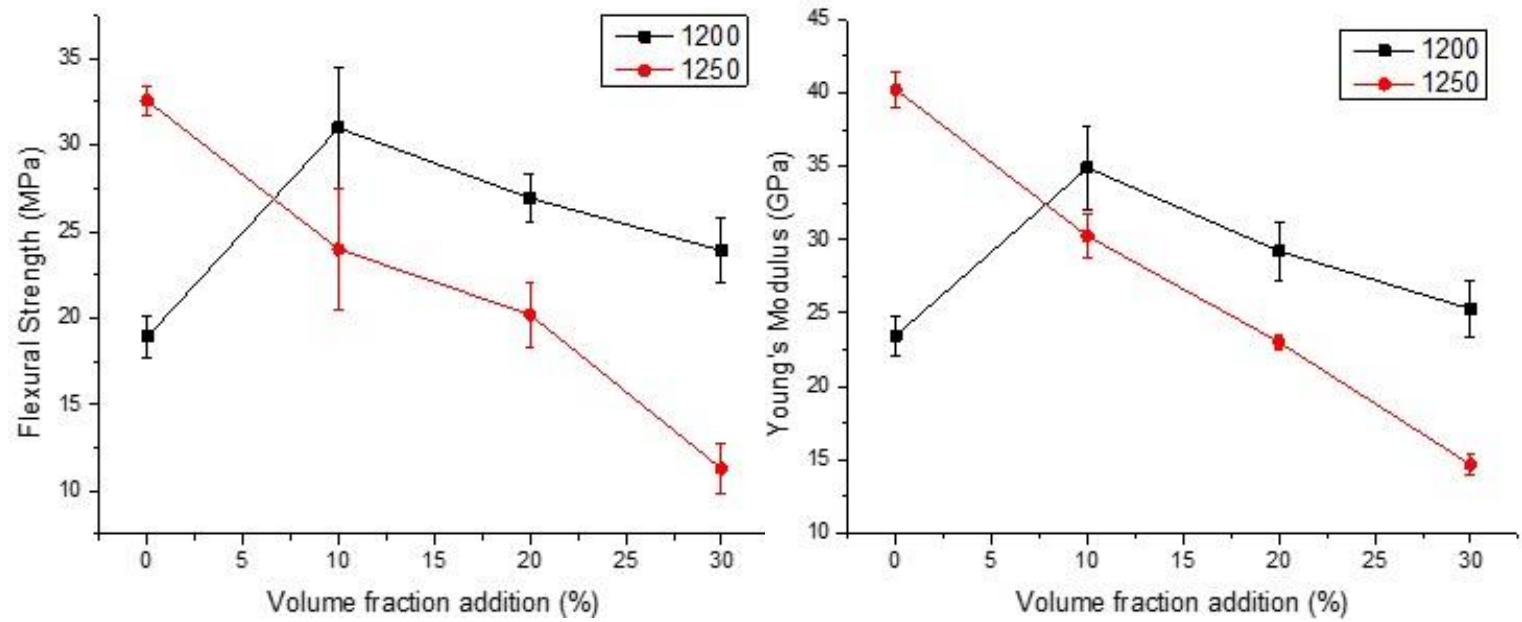

Figure 3: Flexural strength in three-point bending test and Young's modulus

After $10 \%$ of ceramic mixtures addition, each samples value at $1200^{\circ} \mathrm{C}$ were always higher than each samples value at $1250^{\circ} \mathrm{C}$ but never presented higher values than the values of $1250^{\circ} \mathrm{C}$ without addition of ceramic mixture, which in turn, presented the highest flexural strength and Young's modulus in comparison with other samples, $32.58 \mathrm{MPa}$ and $40.22 \mathrm{GPa}$, respectively. In comparison with a porcelain mass study where calcian residues are used as substitutes for feldspar, the samples fired at $1200^{\circ} \mathrm{C}$ presented approximately $35 \mathrm{MPa}$ of flexural strength for the samples without addition of the residues [7]. The highest values of the assessed mechanical properties of samples with $0 \%$ mixture addition of the $1250^{\circ} \mathrm{C}$ were caused by ceramic phases developed at this thermal treatment, where mullite is formed according to literature [8,9], refer Figure 4. Moreover, with increasing addition of ceramic mixture the values of these properties presented a decreasing trend reaching values of $11.29 \mathrm{MPa}$ and $14.68 \mathrm{GPa}$ for $30 \%$ wt addition in $1250^{\circ} \mathrm{C}$, of flexural strength and Young's modulus respectively. This was caused mainly by the quality of the bauxite presented in the mixture, which added ferrous and siliceous content to the red ceramic industry clay. Once the increasing of both of these contents lower melt temperatures in ternary diagrams of $\mathrm{SiO}_{2}-\mathrm{Fe}_{2} \mathrm{O}_{3}-\mathrm{Al}_{2} \mathrm{O}_{3}$, it explains the deleterious influence of the mixture addition to the ceramic mass. The use of bauxite residues (red mud) from north Brazil are presented in the literature and showed flexural strengths lower than $5 \mathrm{MPa}$ [10].
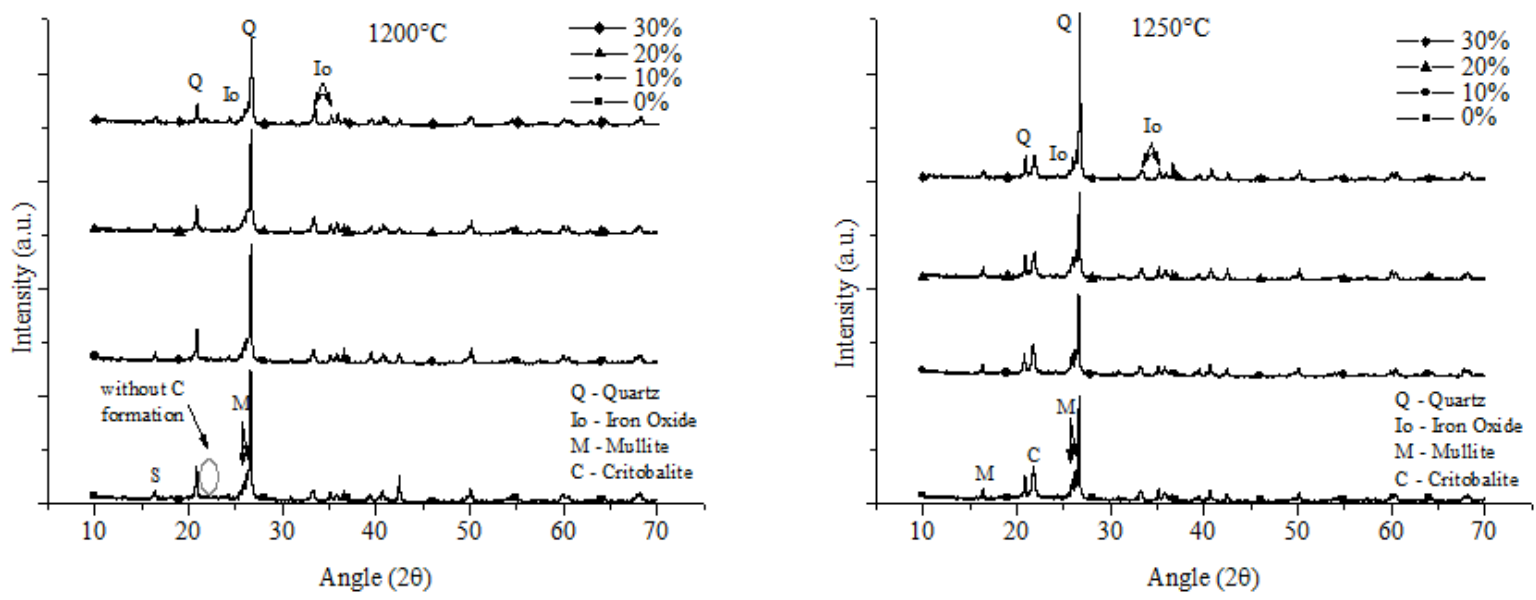

Figure 4: XRD of fired samples at 1200 and 1250 with $10 \%, 20 \%$ and $30 \%$ of addition of kaolin and bauxite mixture. 
The present phases, at thermal treatment temperature of $1200^{\circ} \mathrm{C}$, are mullite, quartz and iron oxide $\left(\mathrm{Fe}_{2} \mathrm{O}_{3}\right)$, which JCPDF reference codes are 01-089-2644, 01-083-2465 and 01-084-0308, respectively. At $1250^{\circ} \mathrm{C}$ cristobalite patterns appear, which is not observed at $1200^{\circ} \mathrm{C}$ as presented in Figure 4 in patterns of $1200^{\circ} \mathrm{C}$, where a circle and an arrow show the absence of this pattern. The formation of this phase is caused by the decomposition of kaolinite, which takes place at temperatures higher than $1200^{\circ} \mathrm{C}$ [4]. The presence of glass formation materials cause crystalline phases to decompose and to incorporate this phases in the glass phase [14]. The addition of the bauxite raw material caused different facts, the increasing of quartz content and the lowering of the mullite phase content, which is in accordance with data available in the literature about triaxial porcelain microstructure development [11].

The ferrous content can also be observed in SEM and OM microstructures imagens as mixture content increases refer Figure 5 and Figure 6.

In SEM imagens ferrous content presents light coloured microstructure of the sample fired $30 \%$ fired at $1200^{\circ} \mathrm{C}$, determined by energy dispersive. In $\mathrm{OM}$ dark coloured microstructure of the sample fired at $1250^{\circ} \mathrm{C}$, both circulated with dashed line. Additionally, samples with higher mixture addition presented after the firing process an overall colour lighter than the samples with lower mixture addition. On the other hand, samples without the mixture addition presented the darkest colour. 


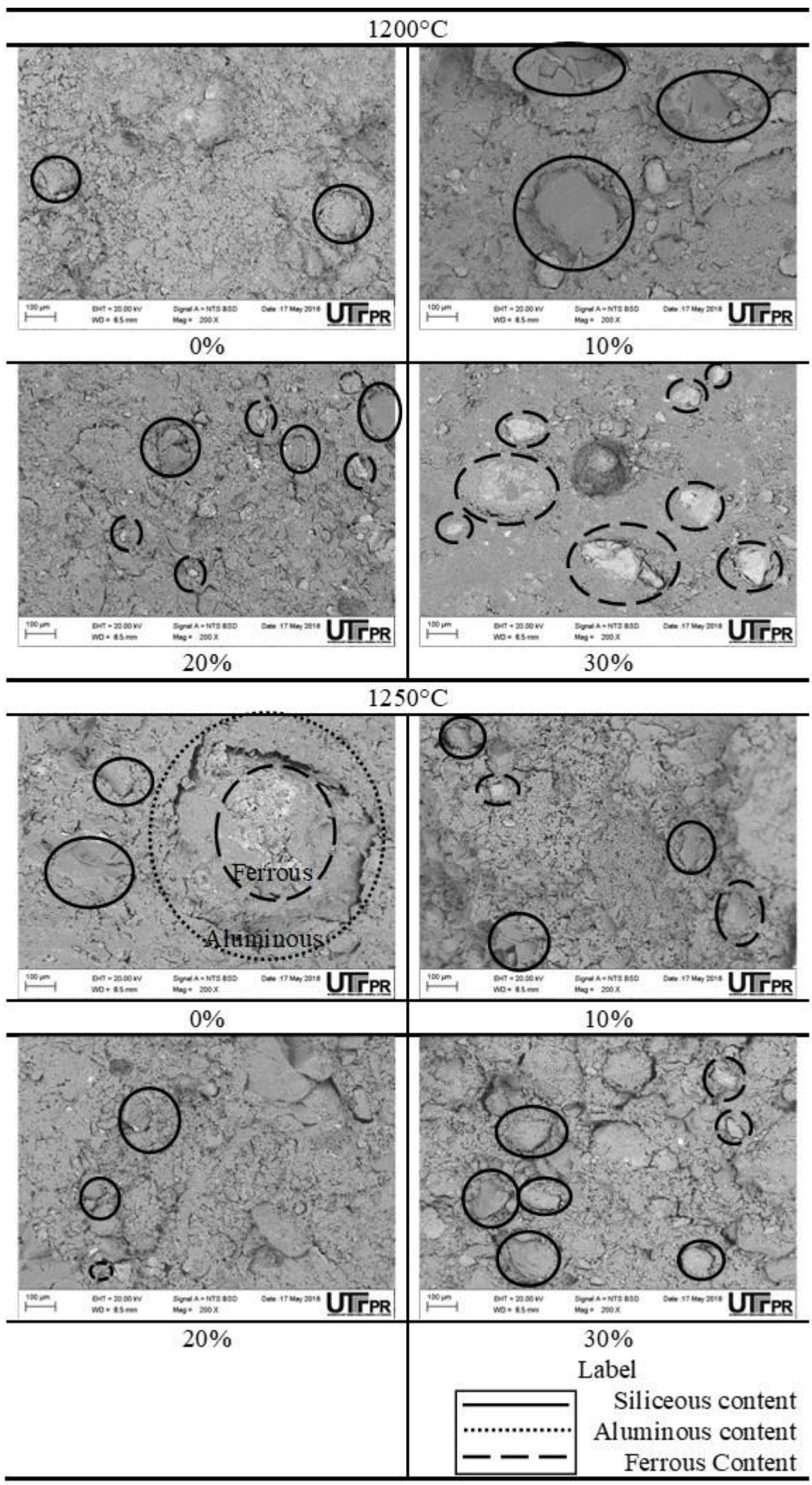

Figure 5: Typical SEM images of the Amazonian region samples fired at $1200^{\circ} \mathrm{C}$ and $1250^{\circ} \mathrm{C}$ 

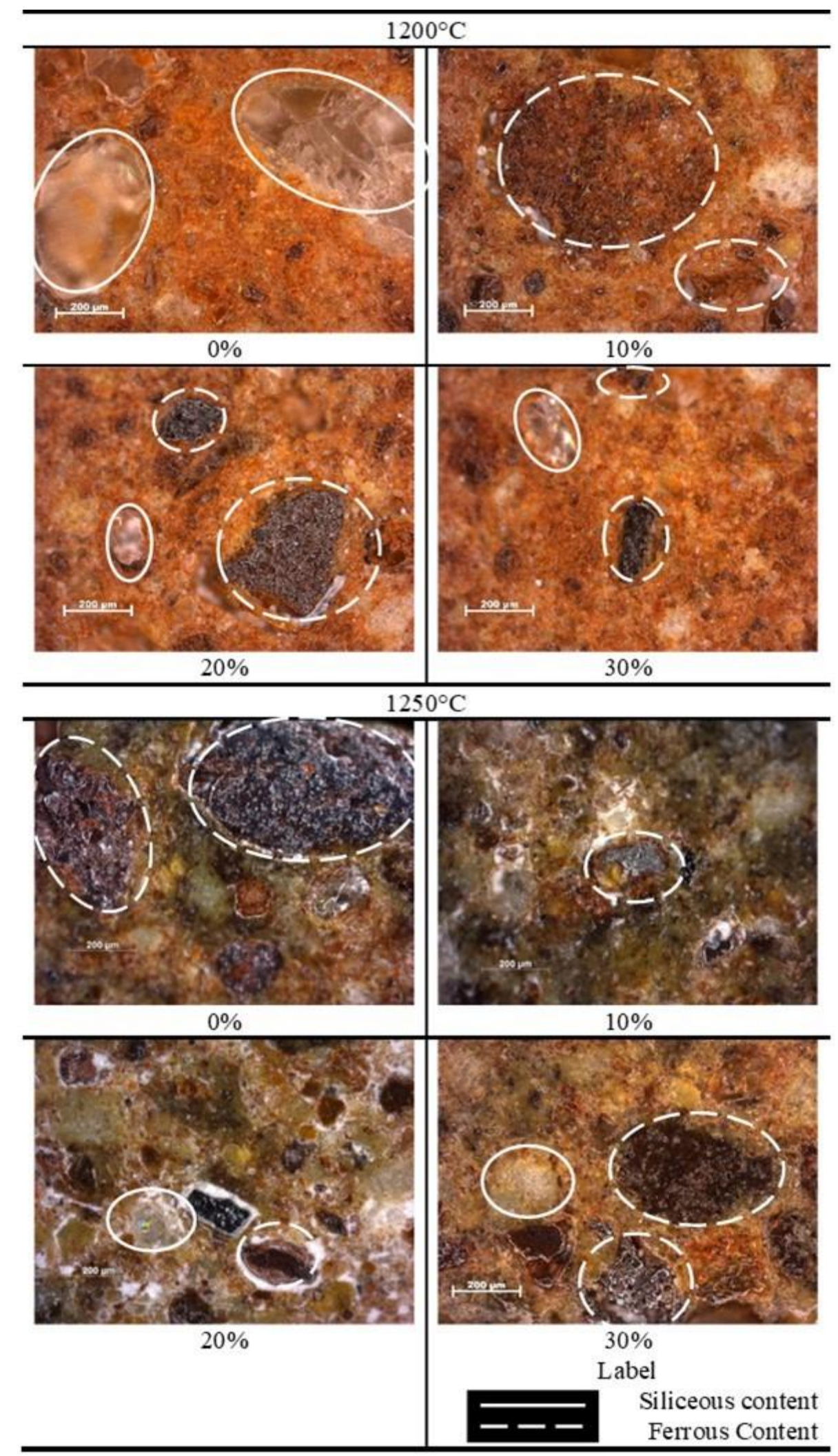

Figure 6: Typical Optical images of the Amazonian region samples fired at $1200^{\circ} \mathrm{C}$ and at $1250^{\circ} \mathrm{C}$ 
Samples fired with higher temperature presented darker colour, which is an observation already referred in the literature elsewhere $[12,13]$. Besides density value of the sample without mixtures addition presented in Figure 7 was not the highest one, it presented lowest porosity value, which has more to do with the influence in flexural strength than density values. In the microstructure of the sample with $0 \%$ mixture addition fired at $1250^{\circ} \mathrm{C}$, the feature in the microstructure circulated with pointed line refers to the aluminous content of the samples, which is addressed to be the mullite phase content.
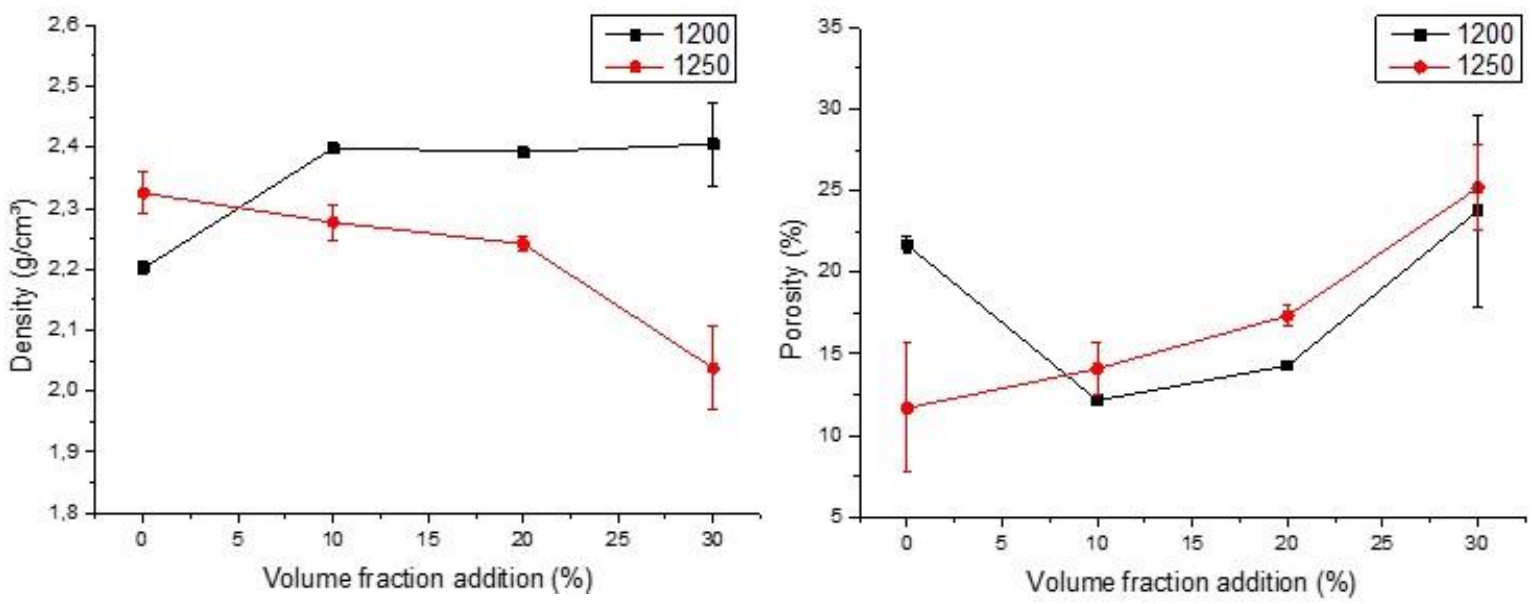

Figure 7: Density and Archimedes' porosity values of the Amazonian region samples fired at $1200^{\circ} \mathrm{C}$ and at $1250^{\circ} \mathrm{C}$.

\section{CONCLUSION}

Although the incorporation of the mixture of bauxite/kaolin to the red ceramic industry clay caused the evaluated properties to decrease, the characterization of the red ceramic industry clay showed interesting information, e.g. high aluminous content and flexural strength of $35 \mathrm{MPa}$, which is the main scientific contribution of this work. The initial idea was to evaluate the addition of the raw material from the vicinity of Manaus city in the red ceramic industry clay and this objective was evaluated and presented itself as deleterious for the analysed properties. Nevertheless, the firing of the red ceramic industry clay at evaluated temperatures showed itself as a promising technological alternative.

\section{ACKNOWLEDGMENTS}

The authors gratefully acknowledge CNPq, for granting project 487532/2012-0, which made the study possible; The FAPEAM Foundation, for the granting of PIBITI scholarships and funds for maintenance of equipment; the Araucária Foundation for the granting of PIBITI scholarships; and to the MontMar red ceramic industry for the suppling raw materials to this work.

\section{BIBLIOGRAPHY}

[1] ARAUJO, R. C. L., RODRIGUES, E. H. V., FREITAS, E. G. A. Materiais de construção, Editora Universidade Rural: Rio de Janeiro, Brasil, p. 18-22, 2000.

[2] FROTA, C. A., NUNES, F.G.R., SILVA, C.L., et al. "Desempenho Mecânico de Mistura Asfálticas Confeccionadas com Agregados Sintéticos de Argila Calcinada”, Cerâmica, v. 53, p. 255-262, 2007.

[3] PINHEIRO, B. C. A., ESTEVÃO, G. M., SOUZA, D. P. "Waterworks waste (sludge) of the Leopoldina, MG, region aiming its use in the red ceramic industry. Part I: characterization of the sludge", Matéria (Rio de Janeiro), v. 19, n. 3, p. 204-211, 2014.

[4] CHEN, C. Y., LAN, G. S., TUAN, W. H. "Preparation of mullite by the reaction sintering of kaolinite and alumina", Journal of the European Ceramic Society, v. 20, n. 14, p. 2519-2525, 2000 a.

[5] CHEN, C. Y., LAN, G. S., TUAN, W. H. "Microstructural evolution of mullite during the sintering of kaolin powder compacts", Ceramics International, v. 26, n. 7, p. 715-720, 2000 b.

[6] ASTM International. Standard Test Method for Dynamic Young's Modulus, Shear Modulus, and Poisson's Ratio by Sonic Resonance. ASTM E1875-13, 2013. 
[7] CHINElATto, A. S. A., CHINELATTO, A.L., FERREIRA, D.E.M., et al. "Estudo da viabilidade do uso de resíduo de polimento de rochas ornamentais em porcelanas”, Matéria (Rio J.), Rio de Janeiro, v. 20, n. 4, pp. 1075-1086, Dec. 2015

[8] IQBAL, Y., LEE, W. E. "Fired porcelain microstructures revisited", Journal of the American Ceramic Society, v. 82, n. 12, p. 3584-3590, 1999.

[9] CARTY, W. M., SENAPATI, U. "Porcelain—raw materials, processing, phase evolution, and mechanical behaviour", Journal of the American Ceramic Society, v. 81, n. 1, p. 3-20, 1998.

[10] RIBEIRO, L. S., BABISK, M.P., PRADO, U.S., et al. "Incorporation of in Natura and Calcined Red Muds into Clay Ceramic", Materials Research, v. 18, pp. 279-282, 2015.

[11] IQBAL, Y., LEE, W. E. "Microstructural evolution in triaxial porcelain", Journal of the American Ceramic Society, v. 83, n. 12, pp. 3121-3127, 2000.

[12] CARGNIN, M., BORGES, D.C.M., SILVA, J.A., et al., "Influência dos tipos de matérias-primas e das condições de queima na cor do suporte cerâmico", Revista Técnico Científica do IFSC, v. 1, n. 2, p. 135, 2012 .

[13] SILVA, A. L., LUNA, C.B.B., CHAVES, A.C., et al., "Technological characterization of new clay deposits in the south region of Amapá aiming applications in the ceramic industry", Matéria (Rio de Janeiro), v. 22, n. 1, 2017.

[14] BRAGANÇA, S. R., BERGMANN, C. P. “Aspectos teóricos e práticos sobre a resistência mecânica de porcelanas", Cerâmica, v. 50, pp. 145-155, 2004. 